Вернигора С. М., канд. наук із сои. комунік., доцент, Інститут журналістики

Київського університету імені Бориса Грінченка
Vernyhora Svitlana,

Candidate of Sciences on Social Communications, Associate Professor, Institute of Journalism of Borys Grinchenko Kyiv University

УДК 655: 303.433.2: [004.738.52]: 02

ШПАК В. І. ПОЛІГРАФІЯ: КНИГА РЕДАКТОРА: НАВЧАЛЬНИЙ ПОСІБНИК. ПОКАЖЧИК ЗМІСТУ

\title{
SHPAK V. I. PRINTING INDUSTRY: EDITOR'S BOOK: TEXTBOOK. CONTENT INDEX
}

Анотація. Кафедра видавничої справи Інституту журналістики Київського університету імені Бориса Грінченка презентує новий навчальний посібник, автором якого є доктор історичних наук, професор, директор видавництва ДП «Експрес-об’ява» В. І. Шпак. «Поліграфія: книга редактора»- перший навчальний посібник серії навчальних видань для вищої школи.

Ключові слова: Шпак В. І., «Поліграфія: книга редактора», навчальний посібник, видавнича справа, Інститут журналістики Киӥвського університету імені Бориса Грінченка.

Abstract. Chair of Publishing Studies of Institute of Journalism of BorysGrinchenko Kyiv University presented a new textbook the author of which is ShpakV. I., D. Sc. (History), Professor, Director of publishing house DP «Ekspres-obiava». «Printing industry:editor's book» is the first textbook of series of educational editions for higher school.

Keywords: Shpak V. I., «Printing industry: editor's book», textbook, publishing studies, Institute of Journalism of Borys Grinchenko Kyiv University.

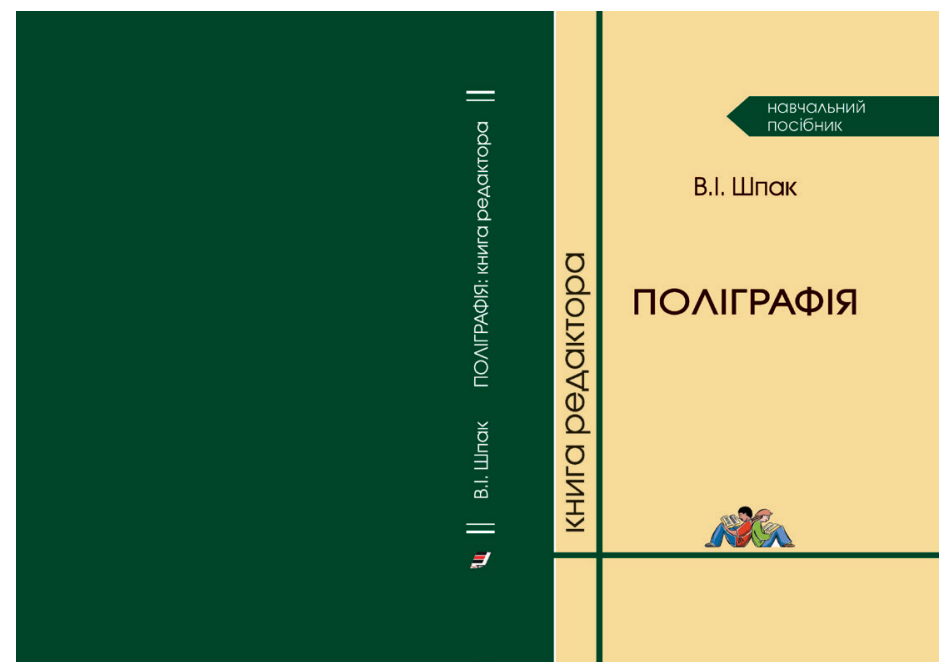

Б ібліографоване джерело: Шпак В. І. Поліграфія: книга редактора : навч. посіб. / В. І. Шпак ; [рец.: Бондар Ю. В., Масімова Л. Г., Олійник В. Г.] ; реком. до друк. рішенням вченої ради Ін-ту жур. Ун-ту Грінченка [протокол № 1 від 22 вер. 2017 р.]. - Київ : ДП «Експрес-об'ява», 2017. - 336 с. - ISSN 978-617-7389-07-0.

(C) Вернигора С. М., 2017
Автор: Шпак Віктор Іванович, д-р іст. наук (дис. «Мале підприемництво видавничої галузі України (1991-2010рр.)»), проф. кафедри видавничої справи Інституту журналістики Київського університету імені Бориса Гринченка; президент і голов. ред. Укр. видав.-поліграф. компанії «Експрес-об'ява» .

Анотація. Навчальний посібник покликаний формувати теоретичну і прикладну бази фахівця з видавничої діяльності та надати цілісне уявлення про друкарську справу, уміння орієнтуватися у реаліях сучасної поліграфічної галузі, розумітися на її технологіях та витратних матеріалах, економічних та організаційних засадах функціонування тощо.

Книга призначена для студентів редакційно-видавничих спеціальностей, видавцівпрактиків, всіх, хто цікавиться видавничою галуззю.

Зміст навчального посібника: В с т у п , 3-4; Р озді л I. Стан та основні тенденції розвитку поліграфії як складової видавничої справи в Україні та світі, 5-18 ; Р оз-

Integrated communications, 201\% 
д і л I . Структура друкарні. Загальні принципи організації (стадії) виконання замовлення на виготовлення поліграфічної продукції, 19-34 : 1. Різновиди друкарень, 19-23; 2. Основні етапи поліграфічного виконання видавничого продукту, 23-25; 3. Структура друкарні, 26-30; 4. Основні етапи роботи видавця 3 поліграфічним підприємством, 30-31; 5. Вимоги друкарні щодо підготовки видавничого оригінал-макету, 32-33, Список використаних джерел ma літератури, 33-34 ; Р о зді л I I I . Додрукарська підготовка, 35-62 : 1. Загальна характеристика, 35-35; 2. Кольоропроба, 35-36; 3. Монтаж спусків смуг. Сигнальний примірник. «Чисті аркуші», 36-40; 4. Системи кольоропередачі: RGB, CMYK, Pantone, HSB, Lab, 40-52; 5. Кольороподіл. Растрування, 52-59; 6. Підготовка паперу і фарби до друку, 59-61, Список використаних джерел та літератури, 61-62 ; Р о з д і л I V . Додрукарська підготовка. Формні процеси, 63-86 : 1. Технологія «комп'ютер - фотоформа» (CtF, «computerto-film»), 63-69; 2. Технологія «комп'ютер - друкарська форма» (CtP, «computer-to-plate»), 69-82; 3. Технологія «комп'ютер - друкарська машина» (CtPress, «computer-to-press»), 82-86, Список використаних джерел та літератури, 86-86 ; Р о зд і л V . Способи друку, 87-146 : 1. Способи друку: загальна характеристика, 87-90; 2. Високий друк, 90-100; 3. Глибокий друк, 101-109; 4. Плоский (офсетний) друк, 109-129; 5. Цифровий друк, 129-135; 6. Спеціальні способи друку, 135-143: Трафаретний друк, 135-139, Тампонний друк, 139-142, Брайлівський друк, 142-143, Інші способи друку, 143-143, Список використаних джерел та літератури, 143-146 ; Р озділ V I . Післядрукарські процеси, 147-208 : 1. Загальна характеристика, 147-150; 2. Палітурно-брошурувальні процеси, 150-191; 3. Оздоблювальні процеси та пакування, 191-207: Лакування, 191-196, Ламінування, 196-198, Тиснення, 198-202, Термографія, 202-202, Висікання, 202-203, Зерніння, 203-203, Бронзування, 203-203, Гумування, 203-203, Бігування, 203-204, Перфорування, 204-204, Круглення кутів, 204-205, Нумерація, 205-205, Пакування, 205-207, Список використаних джерел та літератури, 207-208 ; Р о з д і л V I I . Витратні матеріали та оптимізація витрат, 209-258 : 1. Витратні матеріали в поліграфії, 209-248: Папір, картон 209-216, Офсетні друкарські форми, 216-219, Фарби для друку, 219-224, Офсетне полотно, 224-227, Піддекельні матеріали, 227-228, Зволожуючі розчини, 228-230, Полотна для автоматичного очищення, 230-231, Фототехнічні матеріали, 231-232, Противідмарювальні плівки, 232-233, Противідмарювальний порошок, 233-234,
Палітурні тканини, 234-235, Матеріали для скріплення і обробки книжкового блока, 235-237, Лак, 237-241, Марзани, 241-241, Клей, 241-244, Плівка для ламінування, 244-246, Фольга для тиснення, 246-246, Пакувальні матеріали, 246-247, Допоміжна друкарська хімія, 247-248; 2. Структура собівартості поліграфічного відтворення видавничої продукції та оптимізація витрат, 248-253; 3. Методика обрахунку паперу на виконання поліграфічного замовлення, 253-257, Список використаних джерел та літератури, 257-258; Д о д а т к и , 259-300 : Додаток 1.1. Лідери світового книговидання, 259-259; Додаток 2.1. Організаційні структури управління, 260-260; Додаток 2.2. Технічні вимоги друкарні, 261-276; Додаток 3.1. Деякі форми крапок і шкала тонів растрованого зображення, 277-277; Додаток 3.2. Типова лініатура друку для різних класів поліграфічних паперів і обмеження по «total ink (TIL)», 278-278; Додаток 3.3. Принципи формування регулярного i стохастичного растрів, 279-279; Додаток 3.4. Рекомендоване призначення паперу, 280-280; Додаток 4.1. Основні технічні параметри різних типів формовивідних пристроїв, 281-281; Додаток 4.2. Приклади формовивідних пристроїв, 282-282; Додаток 4.3. Процес запису форм за DICO-технологією, 283283; Додаток 5.1. Системи зволоження в офсетному способі друку, 283-283; Додаток 5.2. Порівняння видів друку, 283-283; Додаток 6.1. Приклейка додаткових елементів, 284-284; Додаток 6.2. Принцип шиття дротом, 285-285; Додаток 6.3. Технологія шиття термонитками, 286-286; Додаток 6.4. Технологічна схема блокообробної лінії «ВF 512» фірми «Kolbus», 287-288; Додаток 6.5. Схема комплектації потокової лінії «Diamant», 289-289; Додаток 6.6. Особливості різних способів лакування, 290-290; Додаток 6.7. Принципова схема машини для припресування плівки клейовим способом, 291-291; Додаток 6.8. Технологічна схема машини для припресування плівки безклейовим способом, 292-292; Додаток 6.9. Класифікація ламінаторів, 293-293; Додаток 7.1. Характеристика основних видів паперу для друку, 294-294; Додаток 7.2. Класифікація паперу для друку за різними ознаками, 295-295; Додаток 7.3. Властивості офсетних гумотканинних полотен, 296-296; Додаток 7.4. Різновиди фольги для тиснення на прикладі продукції компанії «Univacco» (Тайвань), 297-299; Додаток 7.5. Нормативна документація щодо витрат матеріалів на процеси поліграфічного виробництва, розроблені у ВАТ «УНДІПП ім. Т. Шевченка» у 2000-2005 pp., 300-300 ; Г л ос а р і й , 301-332; 3 м і с т , 332-335.

Подано до редакиіï 20. 12. 2017 р.

Інтегровані комунікації, 201\% 
Вернигора С. Н., канд. наук из соц. коммуник., доцент,

Институт журналистики

Киевского университета имени Бориса Гринченко

\section{ШПАК В. И. ПОЛИГРАФИЯ: КНИГА РЕДАКТОРА: УЧЕБНОЕ ПОСОБИЕ. УКАЗАТЕЛЬ СОДЕРЖАНИЯ}

Аннотация. Кафедра издательского дела Института журналистики Киевского университета имени Бориса Гринченко представляют вниманию преподавателей и студентов новое учебное пособие, автором которого является доктор историчних наук, профессор кафедры издательского дела, директор издательства ДП «Експресоб’ява» В. И. Шпак.

«Полиграфия: книга редактора»- это первая книга новой серии учебных пособий для студентов высших учебных заведений, которые изучают издательское дело и редактирование.

Ключевые слова: Шпак В. И., «Полиграфия: книга редактора», учебное пособие, издательское дело, Институт журналистики Киевского университета имени Бориса Гринченко. 